\title{
Chemical composition and antioxidant activity of Cichorium spinosum L. leaves in relation to developmental stage
}

\author{
Spyridon A. Petropoulos ${ }^{\mathrm{a}, *}$, Ângela Fernandes ${ }^{\mathrm{b}}$, Antoniadis Vasileios ${ }^{\mathrm{c}}$, Georgia Ntatsi ${ }^{\mathrm{d}}$, Lillian Barros ${ }^{\mathrm{b}}$, \\ Isabel C.F.R. Ferreira ${ }^{b, *}$
}

${ }^{a}$ Laboratory of Vegetable Production, University of Thessaly, Fytokou Street, 38446 N. Ionia, Magnissia, Greece

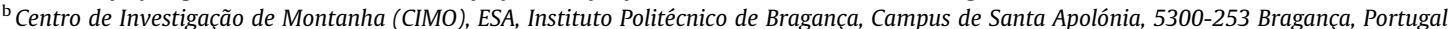

${ }^{c}$ Laboratory of Soil Science, University of Thessaly, Fytokou Street, 38446 N. Ionia, Magnissia, Greece

${ }^{\mathrm{d}}$ Laboratory of Vegetable Production, Agricultural University of Athens, Iera Odos 75, 11855 Athens, Greece

\section{A R T I C L E I N F O}

\section{Article history:}

Received 29 April 2017

Received in revised form 3 July 2017

Accepted 10 July 2017

Available online 12 July 2017

\section{Keywords:}

5-O-Caffeoylquinic acid

Antioxidant activity

Chicoric acid

Fatty acids

Organic acids

Phenolic compounds

Sugars

Tocopherols

\begin{abstract}
A B S T R A C T
In the present study, chemical composition and bioactivity of Cichorium spinosum leaves were examined at different growth stages for optimum harvest stage and end-use assessment. Total fresh weight and number of leaves were higher at 4th growth stage; however, at this stage the end-use is not indicated for raw consumption but mostly for pickled or dried products. Regarding chemical composition, the highest content of tocopherols and minerals was observed in the 1st growth stage, whereas sugars content was the highest in 3rd and 4th growth stage. Polyunsaturated fatty acids content was the highest during the first two growth stages, whereas antioxidant activity, phenolic acids and total phenolic compounds content in the 3rd stage. In conclusion, the results of this study indicate that chemical composition of C. spinosum is highly depended on development stage, and harvest stage should be considered for alternative uses of end-products with high bioactivity.
\end{abstract}

(c) 2017 Elsevier Ltd. All rights reserved.

\section{Introduction}

Cichorium spinosum is a wild edible green, widely appreciated for its high nutritional value and commonly used as a basic ingredient of the so-called Mediterranean diet. Wild C. spinosum plants are usually hand-picked for raw consumption at growth stages which depend on growing conditions, consumer needs and accessibility of growing areas, while cultivated plants can be harvested multiple times during the growing season, as soon as they reach marketable size. Moreover, the fact that the species usually grows in coastal rocky areas which limits accessibility and available harvesting time, while modern life style have shifted consumers' needs towards ready to eat food products, both are responsible for the decrease in wild edible greens consumption during the last decades (Tardío, Pardo-de-santayana, \& Morales, 2006). However, nowadays there is an increasing trend for consumption of

* Corresponding authors at: University of Thessaly, School of Agricultural Sciences, Fytokou Street, 38446 N. Ionia, Magnissia, Greece (S.A. Petropoulos). Instituto Politécnico de Bragança, Campus de Santa Apolónia, 1172, 5300-253 Bragança, Portugal (I.C.F.R. Ferreira).

E-mail addresses: fangio57gr@gmail.com (S.A. Petropoulos), iferreira@ipb.pt (I.C.F.R. Ferreira). "healthy" or "super foods" which have created a market niche for commercial cultivation of wild edible greens (Petropoulos, Ntatsi, Levizou, Barros, \& Ferreira, 2016).

Harvest stage is of the highest importance for marketability of leafy vegetables, since visual quality of the final product defines consumer's acceptance. Apart from appearance, harvest may also affect chemical composition and nutritional value and harvest at the optimum stage could significantly increase quality. There are several reports regarding the effect of harvest stage on nutrients and phytochemicals content of leafy vegetables. Omezzine, Bouaziz, Simmonds, and Haouala (2014) have reported that flavonoids, flavones, flavonols and total phenolics content of Trigonella foenum-graecum $\mathrm{L}$. was the highest during the vegetative growth stage. Moreover, Pokkaew et al. (2013) have reported significant fluctuation of phenolic compounds of Arachis hypogaea L. during the vegetative stage of plants, while Zeghichi, Kallithraka, and Simopoulos (2003) suggested that the optimum stage of harvest for $C$. spinosum leaves is at $40-50$ days after planting.

Although the effect of multiple harvests has been reported in terms of yield for various leafy vegetables (Csizinszky, 1999) and chemical composition of $C$. spinosum in particular (Zeghichi et al. 2003), so far no reports are available regarding the effect of growth 
stage on chemical composition and bioactive compounds content of leafy vegetables, mostly due to their short growing period and the market standards which demand specific plant size. Therefore, the aim of the present study was to assess chemical composition of C. spinosum leaves at various growth stages, in order to evaluate the potential of other uses except for raw consumption, such as extracts, decoctions and pickles, which could increase added value of the final product and availability throughout the season.

\section{Materials and methods}

\subsection{Plant material and growing conditions}

Seedlings of Cichorium spinosum L. (Asteraceae) were obtained from Vianame S.A. (Timpaki, Greece). Seeds of Cichorium spinosum L. (Asteraceae) were sown on September 2nd 2015 in seed trays containing peat, as previously described by Anesti et al. (2016). Young seedlings were transplanted when plants reached the stage of 3-4 true leaves on December 1st, 2015 [90 days after sowing (DAS)] in $2 \mathrm{~L}$ pots containing peat (Klassman-Deilmann KTS2, $1.0 \mathrm{~L}$ ) and perlite $(1.0 \mathrm{~L})$, and put in an unheated plastic greenhouse. Plants were fertilized through the irrigation water at regular intervals with the same amount of nitrogen $\left(300 \mathrm{mg} \mathrm{L}^{-1}\right)$, starting with $50 \mathrm{~mL}$ of nutrient solution per pot and up to $300 \mathrm{~mL}$ per pot towards the end of the growth cycle. Growing conditions (mean, max and min temperature, and Relative Humidity) throughout the experiment are presented in Supplementary Material (Fig. S1).

Leaves were harvested at four different stages of plant development and up to flower initiation (133, 175, 195 and 205 DAS) from different plants each time (with no prior harvests being applied), in order to evaluate the chemical composition of the aerial parts at various growth stages. The studied harvest stages are illustrated in Supplementary Material (Fig. S2). On each harvest day, fresh and dry weight of leaves was measured. Dry weight of fresh leaves was evaluated after oven drying of samples at $72{ }^{\circ} \mathrm{C}$ to a constant weight (approximately for $48 \mathrm{~h}$ ).

\subsection{Chemical composition analyses}

For chemical composition, raw samples of leaves were stored at deep freezing conditions $\left(-80^{\circ} \mathrm{C}\right)$ and freeze-dried prior to analysis.

Free sugars were determined in dried sample powder $(1.0 \mathrm{~g})$, spiked with melezitose as internal standard (IS, $5 \mathrm{mg} / \mathrm{mL}$ ), and extracted with $40 \mathrm{~mL}$ of $80 \%$ aqueous ethanol at $80^{\circ} \mathrm{C}$ for $30 \mathrm{~min}$. The resulting suspension was centrifuged (Centurion K24OR refrigerated centrifuge, West Sussex, UK) at $15,000 \mathrm{~g}$ for $10 \mathrm{~min}$. The supernatant was concentrated at $60{ }^{\circ} \mathrm{C}$ under reduced pressure and defatted three times with $10 \mathrm{~mL}$ of ethyl ether, successively. After concentration at $40^{\circ} \mathrm{C}$, the solid residues were dissolved in water to a final volume of $5 \mathrm{~mL}$ and filtered through $0.2 \mu \mathrm{m}$ nylon filters from Whatman. The analysis was performed by high performance liquid chromatography with a refraction index detector (HPLC-RI; Knauer, Smartline system 1000, Berlin, Germany), as previously described by Barros et al. (2013). The sugars were identified by comparing their retention times with standard compounds and quantification was conducted by comparison with dose-response curves constructed from authentic standards, using the internal standard (IS, melezitose) method (DataApex, Podohradska, Czech Republic).

Organic acids were determined using ultra-fast liquid chromatography coupled to a photodiode array detector (UFLC-DAD). Samples ( $\sim 2 \mathrm{~g}$ ) were extracted by stirring with $25 \mathrm{~mL}$ of metaphosphoric acid $\left(25^{\circ} \mathrm{C}\right.$ at $\left.150 \mathrm{rpm}\right)$ for $45 \mathrm{~min}$ and subsequently filtered through Whatman No. 4 paper. Before analysis, the sample was filtered through $0.2 \mu \mathrm{m}$ nylon filters (Pereira, Barros, Carvalho, \& Ferreira, 2013). The analysis was performed using a Shimadzu 20A series UFLC (Shimadzu Corporation, Kyoto, Japan) and detection was carried out in a DAD, using $215 \mathrm{~nm}$ and $245 \mathrm{~nm}$ (for ascorbic acid) as preferred wavelengths and controlled by LabSolutions multi LC-DAD software (Shimadzu Corporation, Kyoto, Japan). Quantification was performed by area comparison with calibration curves obtained from each standard compound.

Fatty acids were analyzed with a DANI 1000 gas chromatographer (GC, Milan, Italy) coupled to a flame ionization detector (FID), after a transesterification procedure described by Barros et al. (2013). Fatty acids (obtained after Soxhlet extraction) were methylated with $5 \mathrm{~mL}$ of methanol:sulphuric acid:toluene 2:1:1 ( $v: v: v$ ), during at least $12 \mathrm{~h}$ in a bath at $50^{\circ} \mathrm{C}$ and $160 \mathrm{rpm}$; then $3 \mathrm{~mL}$ of deionised water were added, to obtain phase separation; the FAME were recovered with $3 \mathrm{~mL}$ of diethyl ether by shaking in vortex, and the upper phase was passed through a microcolumn of sodium sulphate anhydrous, in order to eliminate the water; the sample was recovered in a vial with Teflon, and before injection the sample was filtered with $0.2 \mu \mathrm{m}$ nylon filter from Whatman. The FAMEs were identified by comparing their retention time with authentic standards and the results were recorded and processed by using Clarity 4.0.1.7 Software (DataApex, Podohradska, Czech Republic).

Tocopherols were determined following a procedure previously described by Barros et al. (2013). BHT solution in hexane (10 mg/ $\mathrm{mL} ; 100 \mu \mathrm{L}$ ) and IS solution in hexane (tocol; $50 \mu \mathrm{g} / \mathrm{mL} ; 400 \mu \mathrm{L}$ ) were added to the sample prior to the extraction procedure. The samples ( $\sim 500 \mathrm{mg})$ were homogenized with methanol $(4 \mathrm{~mL})$ by vortex mixing (1 min). Subsequently, hexane $(4 \mathrm{~mL})$ was added and again vortex mixed for $1 \mathrm{~min}$. After that, saturated $\mathrm{NaCl}$ aqueous solution $(2 \mathrm{~mL})$ was added, the mixture was homogenized ( $1 \mathrm{~min}$ ), centrifuged ( $5 \mathrm{~min}, 4000 \mathrm{~g}$ ) and the clear upper layer was carefully transferred to a vial. The sample was re-extracted twice with hexane. The combined extracts were taken to dryness under a nitrogen stream, redissolved in $2 \mathrm{~mL}$ of $n$-hexane, dehydrated with anhydrous sodium sulphate, filtered through $0.2 \mu$ m nylon filters from Whatman, transferred into a dark injection vial prior to the analysis. The chromatographic separation was achieved using an HPLC (Knauer, Smartline system 1000, Berlin, Germany) coupled to a fluorescence detector (FP-2020; Jasco, Easton, MD, USA), programmed for excitation at $290 \mathrm{~nm}$ and emission at $330 \mathrm{~nm}$. The compounds were identified by chromatographic comparisons with authentic standards and quantification was conducted by comparison with dose-response curves constructed from authentic standards, using the IS (tocol) method (DataApex, Podohradska, Czech Republic).

Oven dried samples of leaves tissues were subjected to dry ashing and extracted with $1 \mathrm{~N} \mathrm{HCl}$ for mineral content determination. $\mathrm{Mg}$, Fe, $\mathrm{Mn}, \mathrm{Zn}$, and $\mathrm{Cu}$ content were determined by atomic absorption spectrophotometry (Perkin Elmer 1100B, Waltham, MA, USA) and $\mathrm{Ca}, \mathrm{Na}$ and $\mathrm{K}$ content by flame photometry (Sherwood Model 410, Cambridge, UK)

Nitrate content was assessed colorimetrically by the nitration of salicylic acid, following the procedure previously described by Cataldo, Maroon, Schrader, and Youngs (1975), using a Perkin Elmer Model Lambda 1A spectrophotometer (Perkin Elmer, Waltham, Mass.).

\subsection{Antioxidant activity assays}

For methanolic/water $(80: 20, v / v)$ extraction, one gram of lyophilized material was extracted twice for $1 \mathrm{~h}$ in a magnetic stirrer plate $\left(25^{\circ} \mathrm{C}\right.$ at $\left.150 \mathrm{rpm}\right)$, with $30 \mathrm{~mL}$ of methanol/water $(80: 20, \mathrm{v} / \mathrm{v})$, filtered through a Whatman No. 4 paper and vacuum-dried in a rotary evaporator (rotary evaporator Büchi R-210, Flawil, 
Switzerland) at $40^{\circ} \mathrm{C}$ to remove the methanol. The extracts were further frozen and lyophilized. Afterwards, the extracts were re-dissolved in methanol/water $(80: 20, v / v)$ for in vitro antioxidant activity assays, at a final concentration of $20 \mathrm{mg} / \mathrm{mL}$ and further diluted to different concentrations.

The antioxidant activity was evaluated by DPPH radicalscavenging activity, reducing power, inhibition of $\beta$-carotene bleaching in the presence of linoleic acid radicals and inhibition of lipid peroxidation using TBARS in brain homogenates (Petropoulos, Fernandes, Barros, Ferreira, \& Ntatsi, 2015). The results were expressed in $\mathrm{EC}_{50}$ values (sample concentration providing $50 \%$ of antioxidant activity of DPPH radical-scavenging activity, inhibition of $\beta$-carotene bleaching and TBARS assays, or 0.5 of absorbance for the reducing power assay) for antioxidant activity and Trolox was used as a positive control.

\subsection{Phenolic compounds analysis}

The above-mentioned extracts [methanolic/water extracts; $(80: 20, v / v)]$ were re-dissolved in methanol/water $(80: 20, v / v)$ at a final concentration of $30 \mathrm{mg} / \mathrm{mL}$, filtered through a $0.45 \mu \mathrm{m}$ Whatman syringe filter, and transferred to amber color HPLC vial for phenolic compound analysis. The phenolic compounds were determined by LC-DAD-ESI/MSn (Dionex Ultimate 3000 UPLC, hermo Scientific, San Jose, CA, USA), as previously described by Bessada, Barreira, Barros, Ferreira, and Oliveira (2016). Double online detection was performed using Diode Array Detector (DAD) with 280, 330 and $370 \mathrm{~nm}$ as preferred wavelengths, and a mass spectrometer (MS). The MS detection was performed in negative mode, using a Linear Ion Trap LTQ XL mass spectrometer (ThermoFinnigan, San Jose, CA, USA) equipped with an ESI source. Phenolic compounds identification was performed by comparing their retention time, UV-Vis and mass spectra with available standard compounds and by comparing the obtained information with available data reported in the literature, giving a tentative identification of the detected compounds. For quantitative analysis, a calibration curve for each available phenolic compound standard (Extrasynthèse, Genay, France) was constructed based on the UV signal, whereas when no commercial standards were available, the quantification was performed through the calibration curve of the most similar available standard.

\subsection{Statistical analyses}

The experiment was laid out in a Completely Randomized Blocks design with 10 pots per treatment and $n=3$. Statistical analysis was carried out with Statgraphics 5.1.plus (Statistical Graphics Corporation). Data were evaluated by analysis of variance, while the means of values were compared by Tukey's HSD Test at $\mathrm{p}<0.05$. For chemical composition analyses, three samples for each treatment were analysed while all the assays were carried out in triplicate. The results are expressed as mean values and standard deviations (SD), and analysed using one-way analysis of variance (ANOVA) followed by Tukey's HSD Test at $\mathrm{p}<0.05$. This analysis was carried out using SPSS v. 22.0 program (IBM Corp., Armonk, NY, USA).

\section{Results and discussion}

The results include limited data (all the data related with the 1st growth stage) that have been presented in another study by the authors (Petropoulos, Fernandes, et al., 2017), where the effect of successive harvesting on chemical composition and bioactive properties of $C$. spinosum leaves was examined. Therefore, these data have been excluded from all the tables and a special mention is given on the abovementioned paper.

Fresh weight and number of leaves are positively correlated and both increase with plant development, considering that leaves are formed in a rosette shaped formation, whereas dry weight showed its highest value at the 2 nd growth stage (Table 1 ). The same results have been observed in other leafy vegetables, which in contrast to fruit vegetables they gain weight by continuously forming new leaves in the meristem apex (Palaniswamy, McAvoy, \& Bible, 2004; Petropoulos, Akoumianakis, \& Passam, 2005). Considering that leafy vegetables are usually intended for raw consumption, harvest at early stages is the common practice since texture and visual quality of leaves are the highest at these stages. However, late harvesting could be also an option for alternative end-uses, such as pickled or dried innovative products.

Chemical composition of leaves changed significantly during the growing period and up to flower initiation where the last harvest took place (4th harvest at 205 DAS). Total organic acids content was higher at the 3rd growth stage (195 DAS), mostly due to higher content of oxalic and quinic acids, followed by a rapid decrease at the last harvest for both organic acids (Table 2). Although Palaniswamy et al. (2004) have reported that oxalic acid decreased significantly in purslane leaves and stems at the stage of 16-true leaves comparing to 8-true leaves, this decreasing trend was only observed at late growth stages of this study (4th growth stage). However, no direct comparison between the species can be made, considering the differences in their growth cycle duration and climate requirements. Ascorbic acid content was the highest at the 3rd growth stage, indicating high nutritional value at this developmental stage (Table 2), while Zeghichi et al. (2003) have also reported a variable ascorbic acid content at different harvest stages. Leafy vegetables are usually considered rich sources of ascorbic acid and contribute significantly to the recommended daily intake; however, there is no consistent trend reported for the various vegetable species regarding the optimum harvest stage for high ascorbic acid content, since many other factors may affect this compound's content (Bergquist, Gertsson, \& Olsson, 2006).

The main identified sugars were sucrose and glucose, while fructose and trehalose were detected in lower amounts (Table 2). Total and individual sugars content increased with plant development with highest values being observed in the 3rd and 4th growth stages. This increase in sugar content with plant development has been also observed for $C$. intybus var. Rosso di Chioggia by Poli et al. (2002), who reported a significant increase of sucrose and fructose, especially in the outer leaves of two selections (C2 and C3) of this variety. However, in the same study sugar content was not significantly correlated with bitter taste of leaves, since bitterness was mostly affected by guaianolide content. In contrast, according to Lin et al. (2013) sugar content is an important quality feature of lettuce leaves. In the same study and the study of Wojciechowska, Dugosz-Grochowska, Koton, and Zupnik (2015), sugar content in lettuce and lamb's lettuce leaves, respectively,

\section{Table 1}

Fresh and dry weight (expressed in g/plant and\% of dry matter, respectively) and number of leaves of Cichorium spinosum plants (mean $\pm \mathrm{SD}$ ) in relation to growth stage.

\begin{tabular}{llll}
\hline Growth stage & Fresh weight & Dry weight & Number of leaves \\
\hline 2nd $^{*}$ & $46.4 \pm 6.5 \mathrm{~b}$ & $9.0 \pm 0.2 \mathrm{a}$ & $38.8 \pm 7.1 \mathrm{~b}$ \\
$3^{\text {rd }}$ & $49.3 \pm 0.6 \mathrm{~b}$ & $8.4 \pm 0.3 \mathrm{~b}$ & $44.1 \pm 7.7 \mathrm{~b}$ \\
$4^{\text {th }}$ & $55.3 \pm 2.3 \mathrm{a}$ & $8.5 \pm 0.5 \mathrm{~b}$ & $52.3 \pm 6.4 \mathrm{a}$ \\
\hline
\end{tabular}

Means of the same column followed by different Latin letters are significantly different according to Tukey HSD test $(\mathrm{P}<0.05)$.

"Data regarding 1 st growth stage have been previously reported by the authors (Petropoulos, Fernandes, et al., 2017). 
Table 2

Composition of organic acids and sugars $(\mathrm{mg} / 100 \mathrm{~g} \mathrm{fw})$ of Cichorium spinosum leaves (mean $\pm \mathrm{SD}$ ) in relation to growth stage.

\begin{tabular}{|c|c|c|c|c|c|c|c|c|c|c|c|}
\hline $\begin{array}{l}\text { Growth } \\
\text { stage }\end{array}$ & Oxalic acid & $\begin{array}{l}\text { Quinic } \\
\text { acid }\end{array}$ & Malic acid & Ascorbic acid & Citric acid & $\begin{array}{l}\text { Total organic } \\
\text { acids }\end{array}$ & Fructose & Glucose & Sucrose & Trehalose & $\begin{array}{l}\text { Total } \\
\text { Sugars }\end{array}$ \\
\hline 2nd ${ }^{*}$ & $51.5 \pm 0.2 b$ & $38.9 \pm 0.3 b$ & $22.99 \pm 0.08 a$ & $0.030 \pm 0.001 b$ & $11.6 \pm 0.1 \mathrm{a}$ & $125 \pm 1 b$ & $180 \pm 2 b$ & $383 \pm 1 b$ & $185 \pm 3 b$ & $52 \pm 2 c$ & $799 \pm 1 b$ \\
\hline $3 r d$ & $66.0 \pm 0.1 \mathrm{a}$ & $52.4 \pm 0.1 \mathrm{a}$ & $23.0 \pm 0.2 a$ & $0.090 \pm 0.001 a$ & $3.1 \pm 0.1 b$ & $145 \pm 1 a$ & $137 \pm 4 c$ & $456 \pm 2 a$ & $412 \pm 9 a$ & $66 \pm 5 b$ & $1070 \pm 1 a$ \\
\hline 4th & $45.5 \pm 1.4 \mathrm{c}$ & $34.4 \pm 0.5 c$ & $18.53 \pm 0.05 b$ & $0.020 \pm 0.001 c$ & $0.14 \pm 0.002 c$ & $100 \pm 2 c$ & $249 \pm 2 a$ & $351 \pm 4 c$ & $406 \pm 1 a$ & $82 \pm 2 a$ & $1087 \pm 3 a$ \\
\hline
\end{tabular}

Means of the same column followed by different Latin letters are significantly different according to Tukey HSD test (P < 0.05 ).

"Data regarding 1st growth stage have been previously reported by the authors (Petropoulos, Fernandes, et al., 2017).

was significantly affected by light quality and intensity, while Wojciechowska et al. (2015) have also observed a significant positive correlation between sugars content and fresh weight of rosettes, which was also the case in our study. Furthermore, sugar composition changes during plant development have been also observed in lettuce plants, with sucrose being the main reserve sugar prior to anthesis, followed by lower molecular weight sugars such as glucose and fructose (Lee \& Sugiyama, 2006).

The fatty acid composition and total fatty acids content is presented in Table 3. The main detected fatty acids were $\alpha$-linolenic, linoleic and palmitic acid, whereas pentadecanoic, palmitoleic, stearic, oleic and behenic acid were detected in lesser amounts. The same fatty acids have been reported in other species of Cichorium, e.g. C. intybus (Morales et al., 2012) and C. spinosum (Petropoulos, Chatzieustratiou, Constantopoulou, \& Kapotis, 2016; Petropoulos, Levizou, et al., 2017; Zeghichi et al., 2003). Polyunsaturated fatty acids (PUFAs) were the main fatty acids

Table 3

Composition of Cichorium spinosum leaves in fatty acids (\%; mean \pm SD) and tocopherols $(\mathrm{mg} / 100 \mathrm{~g} \mathrm{fw})$ in relation to growth stage.

\begin{tabular}{|c|c|c|c|}
\hline & \multicolumn{3}{|l|}{ Growth stage } \\
\hline & 2nd" & 3rd & 4th \\
\hline C6:0 & $0.061 \pm 0.001$ & $0.094 \pm 0.005$ & $0.060 \pm 0.006$ \\
\hline $\mathrm{C} 8: 0$ & $0.041 \pm 0.001$ & $0.069 \pm 0.001$ & $0.084 \pm 0.001$ \\
\hline C10:0 & $0.040 \pm 0.001$ & $0.056 \pm 0.001$ & $0.069 \pm 0.001$ \\
\hline $\mathrm{C} 12: 0$ & $0.065 \pm 0.003$ & $0.068 \pm 0.004$ & $0.156 \pm 0.008$ \\
\hline C14:0 & $0.229 \pm 0.006$ & $0.401 \pm 0.003$ & $1.00 \pm 0.03$ \\
\hline $\mathrm{C} 15: 0$ & $0.349 \pm 0.004$ & $0.331 \pm 0.006$ & $0.752 \pm 0.006$ \\
\hline C16:0 & $8.10 \pm 0.08$ & $10.89 \pm 0.05$ & $14.36 \pm 0.05$ \\
\hline C16:1 & $0.327 \pm 0.004$ & $0.405 \pm 0.001$ & $0.684 \pm 0.008$ \\
\hline C17:0 & $0.105 \pm 0.005$ & $0.183 \pm 0.003$ & $0.328 \pm 0.006$ \\
\hline C18:0 & $0.745 \pm 0.001$ & $1.095 \pm 0.001$ & $1.74 \pm 0.01$ \\
\hline C18:1n9c & $0.765 \pm 0.003$ & $1.20 \pm 0.02$ & $1.14 \pm 0.03$ \\
\hline $\mathrm{C} 18: 2 \mathrm{n} 6 \mathrm{c}$ & $15.33 \pm 0.01$ & $19.33 \pm 0.03$ & $18.21 \pm 0.01$ \\
\hline C18:3n3 & $72.16 \pm 0.09$ & $63.46 \pm 0.06$ & $59.08 \pm 0.08$ \\
\hline C20:0 & $0.24 \pm 0.01$ & $0.43 \pm 0.01$ & $0.447 \pm 0.001$ \\
\hline C20:1 & $0.022 \pm 0.001$ & $0.038 \pm 0.002$ & $0.046 \pm 0.001$ \\
\hline C20:2 & $0.12 \pm 0.01$ & $0.117 \pm 0.005$ & $0.072 \pm 0.001$ \\
\hline$C 20: 3 n 3$ & $0.139 \pm 0.008$ & $0.127 \pm 0.003$ & $0.123 \pm 0.004$ \\
\hline $\mathrm{C} 21: 0$ & $0.027 \pm 0.001$ & $0.067 \pm 0.003$ & $0.087 \pm 0.008$ \\
\hline C20:5n3 & $0.081 \pm 0.001$ & $0.152 \pm 0.008$ & $0.21 \pm 0.02$ \\
\hline $\mathrm{C} 22: 0$ & $0.287 \pm 0.008$ & $0.458 \pm 0.024$ & $0.446 \pm 0.001$ \\
\hline$C 23: 0$ & $0.092 \pm 0.008$ & $0.196 \pm 0.007$ & $0.225 \pm 0.009$ \\
\hline $\mathrm{C} 24: 0$ & $0.67 \pm 0.01$ & $0.84 \pm 0.01$ & $0.69 \pm 0.03$ \\
\hline Total SFA (\% of total FA) & $11.05 \pm 0.10 \mathrm{c}$ & $15.18 \pm 0.04 b$ & $20.45 \pm 0.13 a$ \\
\hline $\begin{array}{l}\text { Total MUFA (\% of total } \\
\text { FA) }\end{array}$ & $1.11 \pm 0.01 \mathrm{~d}$ & $1.65 \pm 0.02 b$ & $1.87 \pm 0.02 \mathrm{a}$ \\
\hline Total PUFA (\% of total FA) & $87.84 \pm 0.10 b$ & $83.18 \pm 0.02 c$ & $77.68 \pm 0.11 d$ \\
\hline alpha-Tocopherol & $0.302 \pm 0.004 c$ & $0.563 \pm 0.005 b$ & $0.717 \pm 0.004 a$ \\
\hline beta-Tocopherol & $0.008 \pm 0.001 \mathrm{c}$ & $0.011 \pm 0.001 b$ & $0.021 \pm 0.001 a$ \\
\hline gamma-Tocopherol & $0.478 \pm 0.004 a$ & $0.320 \pm 0.005 b$ & $0.152 \pm 0.001 c$ \\
\hline delta-Tocopherol & $0.002 \pm 0.001$ & $\operatorname{tr}^{* *}$ & $\operatorname{tr}$ \\
\hline Total Tocopherols & $0.791 \pm 0.008 b$ & $0.894 \pm 0.001 \mathrm{a}$ & $0.891 \pm 0.002 \mathrm{a}$ \\
\hline
\end{tabular}

Means of the same raw followed by different Latin letters are significantly different according to Tukey HSD test $(\mathrm{P}<0.05)$.

"Data regarding 1st growth stage have been previously reported by the authors (Petropoulos, Fernandes, et al., 2017).

tr: $<0.001 \mathrm{mg} / 100 \mathrm{~g} \mathrm{fw}$. class, consisting mostly of $\alpha$-linolenic and linoleic acids which showed a decreasing trend with plant development, followed by a proportionate increase of saturated fatty acids and palmitic acid in particular. This decreasing trend of PUFAs could be associated with high metabolic rates during plant development, especially prior to flower initiation and flower stalk formation, since longchain fatty acids are essential energy sources for plant metabolic pathways (Graham \& Eastmond, 2002). In addition, the gradual decrease of PUFAs could be due to lower tocopherols content (Table 3) which have been reported to have a protective role against lipid oxidation (Cao et al., 2015). The detected ratios of PUFA/SFA and n-6/n-3 fatty acids at the various growth stages of the present study can be considered as beneficial for health, since high intake of n-6 fatty acids has been associated with many chronic diseases, such as coronary heart disease, hypertension and type 2 diabetes (Simopoulos, 1999). According to Zeghichi et al. (2003), fatty acids composition of $C$. spinosum showed a great variation at successive harvests and is highly dependent on harvest stage. Moreover, in the same study a significant decrease of palmitic and linoleic acid was observed after 30 and 40 days from transplantation, whereas $\alpha$-linolenic decreased after 50 days from transplantation. However, the fatty acids evaluation in that study was carried out in plants successively harvested in regular intervals, comparing to our study where plants were only harvested once at each growth stage. To our knowledge this is the first report regarding the fatty acids composition of $C$. spinosum leaves at different growth stages.

Tocopherols content was significantly affected by growth stage for both total tocopherols and individual vitamers (Table 3 ). The main detected tocopherols were alpha- and gamma-tocopherols which showed an inversely proportional trend between the various growth stages. The increase of alpha-tocopherol during C. spinosum development could be associated with more stressful conditions due to high temperatures at late growth stages (early to midspring), comparing to earlier stages (winter). This response of alpha-tocopherol to high temperatures has been confirmed in soybean seeds (Glycine max L.) by Chennupati, Seguin, and Liu (2011) who further noted that the decrease is also cultivar dependent. Similarly, Zeghichi et al. (2003) have reported a decrease of alpha-tocopherol content in C. spinosum plants during growing period, despite the fact that they evaluated it in successively harvested leaves and not in different developmental stages. The effect of developmental stage on tocopherols content has been reported for other species, such as members of the Brassicaceae family (Björkman et al., 2011), Zingiber zerumbet L. (Ghasemzadeh et al., 2016), Momordica charantia L. (Dhillon et al., 2016) and so forth.

Mineral content decreased significantly during plant development with the lowest content being observed prior to flower initiation at the 4th growth stage (Table 4). Moreover, mineral content values were within the range reported by Petropoulos, Levizou, et al. (2017) who evaluated different ecotypes of $C$. spinosum. Similar decreasing trends in mineral content of $C$. spinosum leaves at late growth stages have been also by Zeghichi et al. (2003), although they analysed minerals content in leaves successively harvested at regular intervals. This decreasing trend could be due 
Table 4

Mineral composition and nitrates content $(\mathrm{mg} / 100 \mathrm{~g} \mathrm{fw})$ of Cichorium spinosum leaves (mean \pm SD) in relation to growth stage.

\begin{tabular}{|c|c|c|c|c|c|c|c|c|}
\hline Growth stage & $\mathrm{K}$ & $\mathrm{Na}$ & $\mathrm{Ca}$ & $\mathrm{Mg}$ & $\mathrm{Zn}$ & $\mathrm{Mn}$ & $\mathrm{Fe}$ & $\mathrm{NO}_{3}$ \\
\hline 2nd" & $385.6 \pm 26.0 a$ & $61.5 \pm 11.8 a$ & $252.3 \pm 52.5 a$ & $37.4 \pm 3.0 \mathrm{a}$ & $0.28 \pm 0.06 a$ & $0.64 \pm 0.02 a$ & $0.62 \pm 0.02 a$ & $121.2 \pm 26.4 \mathrm{a}$ \\
\hline $3 r d$ & $347.3 \pm 59.5 c$ & $54.2 \pm 9.7 b$ & $178.0 \pm 35.3 b$ & $33.5 \pm 6.0 \mathrm{~b}$ & $0.22 \pm 0.01 b$ & $0.60 \pm 0.02 b$ & $0.61 \pm 0.06 a$ & $70.2 \pm 12.7 b$ \\
\hline 4th & $362.4 \pm 32.1 b$ & $43.2 \pm 10.1 c$ & $142.6 \pm 12.5 c$ & $29.4 \pm 2.2 c$ & $0.17 \pm 0.01 c$ & $0.59 \pm 0.04 c$ & $0.54 \pm 0.01 b$ & $112.8 \pm 25.6 a$ \\
\hline
\end{tabular}

Means of the same column followed by different Latin letters are significantly different according to Tukey HSD test (P < 0.05).

"Data regarding 1st growth stage have been previously reported by the authors (Petropoulos, Fernandes, et al., 2017).

to the fact that transition of plants from vegetative to reproductive stage is probably not related with plant size (number of produced leaves) but with environmental conditions (temperature and photoperiod) which could induce anthesis despite the number of leaves. Therefore, even regularly harvested plants proceed to reproductive stage, despite the number of formed leaves. The decrease in mineral content observed at the latest growth stages of our study could be correlated with redistribution of minerals towards the tissues that are more metabolically active, since flower initiation is linked to flower stalk elongation and flowers formation (Watanabe et al., 2016); however, this assumption cannot be confirmed in the present study since flower stalks were not analysed for their mineral content.

Nitrate content fluctuated throughout the growing season, with the highest content being detected at the 2nd and 4th growth stage. This trend could be partially explained by growing conditions, especially light quality and intensity which has an important role in nitrates reduction to nitrites by nitrate reductase (Campbell, 1999), as well as by accumulation of nitrates at later stages of plant development for osmoregulation and remobilization purposes (Masclaux-Daubresse et al., 2010). According to Lin et al. (2013), nitrate content in lettuce leaves was significantly affected by light quality, while Petropoulos, Chatzieustratiou, et al. (2016) have reported the effect of harvest time, growing period and nitrogen fertilization rates on nitrates content of parsley leaves. Moreover, Gent (2012) has reported that nitrate content in leafy vegetables is inversely related with organic acids and sugar content, which was also the case in our study and especially for the 3rd growth stage where nitrate content decrease was followed by an increase in organic acids and sucrose content.

The detected phenolic compounds and their identification data are presented in Table 5. Identification of phenolic compounds was carried out and cross checked through their mass spectrum, UV absorption and chromatograms. Fourteen different phenolic compounds were detected in total for all the studied growth stages. All the detected compounds have been previously identified by Petropoulos, Levizou, et al. (2017) in C. spinosum leaves. Compounds 1 and 3 (5-O-caffeoylquinic acid and chicoric acid, respectively) were the main compounds in every growth stage. Moreover, total phenolic compounds consisted mostly of phenolic acids, especially in the 3rd growth stage where $80 \%$ of total phenolic compounds were phenolic acids. Both compounds have been associated with various bioactive effects such as antiinflammatory, antioxidant and anti-obesity properties, while in vitro studies have confirmed their antidiabetic effects (Brieudes et al., 2016; Zhu, Wang, Du, Liu, \& Liu, 2015). Therefore, considering the high content of leaves in these compounds at late developmental stages (3rd stage), alternative uses for pharmaceutical purposes can be proposed.

Phenolic composition was also affected by growth stage, with compounds 9 and 14 (3,5-O-dicaffeoylquinic acid and isorhamnetin-3-O-(6"-O-acetyl)-glucoside, respectively) being detected only in the 1st growth stage (Petropoulos, Fernandes, et al., 2017). Zeghichi et al. (2003) have also reported fluctuation of total phenolic compounds content in successively harvested $C$. spinosum leaves. According to Brieudes et al. (2016), chicoric acid was one of the main antioxidant compounds detected in water decoctions of $C$. spinosum and $C$. intybus leaves, while Jaiswal, Kiprotich, and Kuhnert (2011) have identified the same phenolic acid in $C$. intybus. 5-O-caffeoylquinic acid has also been positively identified in C. intybus leaves in many studies so far (Carazzone, Mascherpa, Gazzani, \& Papetti, 2013; Jaiswal et al., 2011). In the study of Rees and Harborne (1985), who evaluated sesquiterpene lactones and phenolic acids content at various growth stages of C. intybus, it was supported that chicoric acid content fluctuated during the growing season, while significant differences were observed between leaves at different positions on the plant. In the same study, it was suggested that sesquiterpene lactones and phenolic acids have a protective role against herbivore insects; therefore, their content fluctuates during the growing season according to physiological stages of plants and their pests.

Antioxidant properties of $C$. spinosum leaves were determined with four different assays (Table 6), which all indicate the 3rd growth stage as the most appropriate stage of leaves for high antioxidant potency according to the obtained $\mathrm{EC}_{50}$ values. The increase in antioxidant activity at the 3rd growth stage is highly associated with the increased content of bioactive compounds, such as ascorbic acid, phenolic acids and total phenolic compounds (Tables 2 and 5), whereas tocopherols content seems that is not significantly correlated with the antioxidant properties of $C$. spinosum leaves (Table 3). Similar results have been reported by Brieudes et al. (2016), who evaluated the antioxidant properties of water decoctions of $C$. spinosum leaves and suggested a significant correlation of antioxidant potency with phenolic compounds. Pereira, Barros, Carvalho, and Ferreira (2011) have also suggested phenolic compounds content to be linearly correlated with antioxidant activity of various wild edible greens, with different correlations between the various classes of phenolic compounds and the tested assays. Considering that harvests at late growth stages may have a negative effect on edibility and digestibility of leaves due to harsh texture and high content of fibres, their alternative uses as extracts, decoctions or pickles could have a great potential in the food and pharmaceutical industry due to their high content in antioxidant compounds.

\section{Conclusions}

The results of the present study suggest that chemical composition and bioactive compounds content of leaves is significantly modified during plant development. Although leaves intended for raw consumption are usually harvested at early stages, other end-uses could be possible for leaves harvested at later stages, especially prior and during flowering initiation where phenolic compounds content and antioxidant properties of leaves were the highest. In conclusion, apart from raw consumption, pickled products, water extracts or decoctions are also possible to be prepared ensuring better product availability throughout the year, as well as alternative end-use products with high added value for the food and pharmaceutical industry. Therefore, harvesting at the proper developmental stage should be considered as a means of manipulating chemical composition and bioactive properties of leaves. 
Table 5

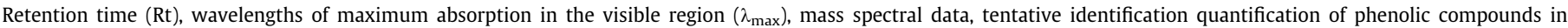
Cichorium spinosum $(\mathrm{mg} / \mathrm{g}$ extract, mean $\pm \mathrm{SD})$ in relation to the development stage.

\begin{tabular}{|c|c|c|c|c|c|c|c|c|}
\hline \multirow[t]{2}{*}{ Peak } & \multirow{2}{*}{$\begin{array}{l}\text { Rt } \\
(\min )\end{array}$} & \multirow{2}{*}{$\begin{array}{l}\lambda_{\max } \\
(\mathrm{nm})\end{array}$} & \multirow{2}{*}{$\begin{array}{l}{[\mathrm{M}-\mathrm{H}]^{-}} \\
(m / z)\end{array}$} & \multirow[t]{2}{*}{$\operatorname{MS}^{2}(m / z)$} & \multirow[t]{2}{*}{ Tentative identification } & \multicolumn{3}{|l|}{ Growth stage } \\
\hline & & & & & & $2 n d^{*}$ & 3rd & 4th \\
\hline 1 & 7.1 & 325 & 353 & 191(100),179(5),173(3),161(3),135(3) & 5-O-Caffeoylquinic acid ${ }^{1}$ & $3.51 \pm 0.08$ & $6.99 \pm 0.02$ & $6.7 \pm 0.1$ \\
\hline 2 & 12.0 & 313 & 337 & $191(100), 173(3), 163(10), 145(3), 119(3)$ & p-Coumaroylquinic acid ${ }^{2}$ & $0.179 \pm 0.008$ & $0.388 \pm 0.002$ & $0.199 \pm 0.001$ \\
\hline 3 & 12.4 & 328 & 473 & $\begin{array}{l}311(100), 293(94), 219(3), 179(7), \\
149(3), 135(3)\end{array}$ & Chicoric acid ${ }^{3}$ & $5.33 \pm 0.03$ & $10.27 \pm 0.01$ & $4.8 \pm 0.1$ \\
\hline 4 & 13.6 & 327 & 367 & $193(10), 191(100), 173(5), 143(3), 134(3)$ & 5-O-Feruolyquinic acid ${ }^{4}$ & $0.010 \pm 0.001$ & nd & $0.434 \pm 0.001$ \\
\hline 5 & 16.5 & 328 & 193 & $178(20), 134(100), 117(8)$ & Ferulic acid ${ }^{4}$ & $0.141 \pm 0.003$ & $0.078 \pm 0.001$ & $0.147 \pm 0.002$ \\
\hline 6 & 18.2 & 342 & 477 & $301(100)$ & Quercetin-3-0-glucuronide ${ }^{5}$ & $0.757 \pm 0.001$ & $0.576 \pm 0.003$ & $1.634 \pm 0.001$ \\
\hline 7 & 18.7 & 348 & 461 & $285(100)$ & Kaempferol-O-glucuronide ${ }^{6}$ & $1.77 \pm 0.01$ & $2.20 \pm 0.01$ & $2.833 \pm 0.005$ \\
\hline 8 & 20.5 & 360 & 505 & $463(26), 301(100)$ & $\begin{array}{l}\text { Quercetin-7-O-(6"-O-acetyl)- } \\
\text { glucoside }^{5}\end{array}$ & $0.226 \pm 0.001$ & $0.246 \pm 0.002$ & $0.408 \pm 0.009$ \\
\hline 9 & 20.9 & 329 & 515 & $\begin{array}{l}353(100), 191(97), 179(48), 173(5), \\
161(3), 135(7)\end{array}$ & $3,5-O$-Dicaffeoylquinic acid ${ }^{1}$ & $\mathrm{nd}^{* *}$ & nd & nd \\
\hline 10 & 22.2 & 345 & 461 & $285(100)$ & Kaempferol-3-O-glucuronide ${ }^{6}$ & $0.915 \pm 0.004$ & $0.806 \pm 0.003$ & $2.104 \pm 0.003$ \\
\hline 11 & 23.4 & 337 & 447 & $269(100)$ & Apigenin- $O$-glucuronide ${ }^{7}$ & $0.238 \pm 0.001$ & $0.236 \pm 0.002$ & nd \\
\hline 12 & 23.7 & 350 & 491 & $315(100)$ & Isorhamnetin-3-O-glucuronide $^{5}$ & $0.233 \pm 0.001$ & $0.229 \pm 0.001$ & $0.364 \pm 0.001$ \\
\hline 13 & 25.0 & 345 & 489 & $285(100)$ & $\begin{array}{l}\text { Kaempferol-3-O-(6"-O-acetyl)- } \\
\text { glucoside }^{6}\end{array}$ & $0.047 \pm 0.001$ & $0.140 \pm 0.002$ & $0.286 \pm 0.004$ \\
\hline \multirow[t]{4}{*}{14} & 26.3 & 334 & 519 & $477(5), 315(100)$ & $\begin{array}{l}\text { Isorhamnetin-3-O-(6" }-0 \text {-acetyl)- } \\
\text { glucoside }^{5}\end{array}$ & $\mathrm{nd}^{* *}$ & nd & nd \\
\hline & & & & & Total phenolic acids & $9.2 \pm 0.1 c$ & $17.733 \pm 0.008 a$ & $12.31 \pm 0.03 b$ \\
\hline & & & & & Total flavonoids & $4.18 \pm 0.01 c$ & $4.429 \pm 0.003 b$ & $7.63 \pm 0.01 a$ \\
\hline & & & & & Total phenolic compounds & $13.4 \pm 0.1 c$ & $22.162 \pm 0.004 a$ & $19.94 \pm 0.02 b$ \\
\hline
\end{tabular}

"Data regarding 1st growth stage have been previously reported by the authors (Petropoulos, Fernandes, et al., 2017).

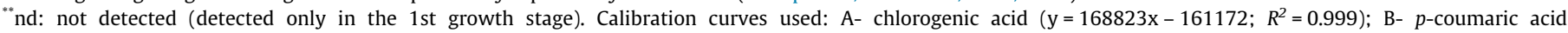

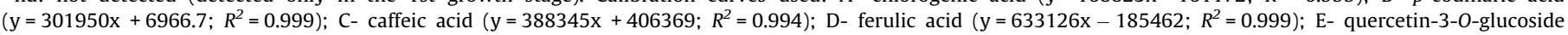
$\left(\mathrm{y}=34843 \mathrm{x}-160173 ; R^{2}=0.999\right) ; \mathrm{F}-$ kaempferol-3-O-rutinoside $\left(\mathrm{y}=11117 \mathrm{x}+30861 ; R^{2}=0.999\right) ; \mathrm{G}-$ apigenin-7-0-glucoside $\left(\mathrm{y}=10683 \mathrm{x}-45794 ; R^{2}=0.996\right)$.

Means of the same raw followed by different Latin letters are significantly different according to Tukey HSD test (P < 0.05$)$.

Table 6

Antioxidant properties of Cichorium spinosum leaves (mean $\pm \mathrm{SD}$ ) in relation to growth stage.

\begin{tabular}{|c|c|c|c|c|}
\hline \multirow[t]{2}{*}{ Growth stage } & \multirow{2}{*}{$\begin{array}{l}\text { Reducing power } \\
\text { Ferricyanide/Prussian blue } \\
\left(\mathrm{EC}_{50} ; \mathrm{mg} / \mathrm{mL}\right)\end{array}$} & \multicolumn{2}{|l|}{ Radical scavenging activity } & \multirow{2}{*}{$\begin{array}{l}\text { Lipid peroxidation inhibition } \\
\text { TBARS }\left(\mathrm{EC}_{50} ; \mathrm{mg} / \mathrm{mL}\right)\end{array}$} \\
\hline & & $\begin{array}{l}\text { DPPH scavenging activity } \\
\left(\mathrm{EC}_{50} ; \mathrm{mg} / \mathrm{mL}\right)\end{array}$ & $\begin{array}{l}\beta \text {-carotene/linoleate } \\
\left(\mathrm{EC}_{50} ; \mathrm{mg} / \mathrm{mL}\right)\end{array}$ & \\
\hline $2 \mathrm{nd}^{*}$ & $0.656 \pm 0.008 b$ & $1.45 \pm 0.06 a$ & $0.74 \pm 0.03 b$ & $0.32 \pm 0.02 b$ \\
\hline 3rd & $0.458 \pm 0.008 c$ & $0.818 \pm 0.009 c$ & $0.69 \pm 0.02 c$ & $0.31 \pm 0.02 b$ \\
\hline 4th & $0.683 \pm 0.011 \mathrm{a}$ & $1.37 \pm 0.06 b$ & $1.00 \pm 0.03 a$ & $0.44 \pm 0.01 \mathrm{a}$ \\
\hline
\end{tabular}

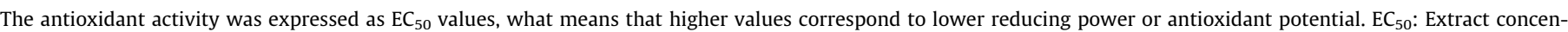

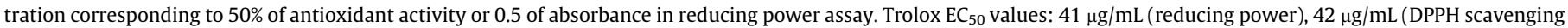
activity), $18 \mu \mathrm{g} / \mathrm{mL}$ ( $\beta$-carotene bleaching inhibition) and $23 \mu \mathrm{g} / \mathrm{mL}$ (TBARS inhibition).

Means of the same column followed by different Latin letters are significantly different according to Tukey HSD test (P < 0.05$)$.

"Data regarding 1st growth stage have been previously reported by the authors (Petropoulos, Fernandes, et al., 2017).

\section{Acknowledgments}

The authors would like to thank Miss Constantina Fassoli and Stavroula Anesti for their technical assistance throughout the experiment. The authors are also grateful to the Foundation for Science and Technology (FCT, Portugal) and FEDER under Programme PT2020 for financial support to CIMO (UID/ AGR/00690/2013) and L. Barros (SFRH/BPD/107855/2015) grant.

\section{Appendix A. Supplementary data}

Supplementary data associated with this article can be found, in the online version, at http://dx.doi.org/10.1016/j.foodchem.2017. 07.043 .

\section{References}

Anesti, S., Fasoli, K., Petropoulos, S., Ntatsi, G., Antoniadis, V., \& Ferreira, I. C. F. R (2016). Effect of ammonium fertilizer on growth and quality of Cichorium spinosum plants. In VII International Scientific Agriculture Symposium "Agrosym 2016" (pp. 827-833).
Barros, L., Pereira, E., Calhelha, R. C., Dueñas, M., Carvalho, A. M., Santos-Buelga, C., \& Ferreira, I. C. F. R. (2013). Bioactivity and chemical characterization in hydrophilic and lipophilic compounds of Chenopodium ambrosioides L. Journal of Functional Foods, 5(4), 1732-1740. http://dx.doi.org/10.1016/j. jff.2013.07.019.

Bergquist, S. Å. M., Gertsson, U. E. \& Olsson, M. E. (2006). Influence of growth stage and postharvest storage on ascorbic acid and carotenoid content and visual quality of baby spinach (Spinacia oleracea L.). Journal of the Science of Food and Agriculture, 86(3), 346-355. http://dx.doi.org/10.1002/jsfa.2373.

Bessada, S. M. F., Barreira, J. C. M., Barros, L., Ferreira, I. C. F. R. \& Oliveira, M. B. P. P. (2016). Phenolic profile and antioxidant activity of Coleostephus myconis (L.) Rchb.f.: An underexploited and highly disseminated species. Industrial Crops and Products, 89, 45-51. http://dx.doi.org/10.1016/j.indcrop.2016.04.065.

Björkman, M., Klingen, I., Birch, A. N. E., Bones, A. M., Bruce, T. J. A., Johansen, T. J., ... Stewart, D. (2011). Phytochemicals of Brassicaceae in plant protection and human health - Influences of climate, environment and agronomic practice. Phytochemistry, 72(7), 538-556. http://dx.doi.org/10.1016/j.phytochem.2011. 01.014.

Brieudes, V., Angelis, A., Vougogiannopoulos, K., Pratsinis, H., Kletsas, D., Mitakou, S., ... Skaltsounis, L. A. (2016). Phytochemical analysis and antioxidant potential of the phytonutrient-rich decoction of Cichorium spinosum and C. intybus. Planta Medica, 82(11/12), 1070-1078.

Campbell, W. H. (1999). Nitrate reductase structure, function and regulation: Bridging the gap between biochemistry and physiology. Annual Review of Plant Physiology and Plant Molecular Biology, 50, 277-303. http://dx.doi.org/10.1146/ annurev.arplant.50.1.277. 
Cao, J., Li, H., Xia, X., Zou, X.-G., Li, J., Zhu, X.-M., \& Deng, Z.-Y. (2015). Effect of fatty acid and tocopherol on oxidative stability of vegetable oils with limited air. International Journal of Food Properties, 18(4). http://doi.org/http://dx.doi.org/10. 1080/10942912.2013.864674.

Carazzone, C., Mascherpa, D., Gazzani, G., \& Papetti, A. (2013). Identification of phenolic constituents in red chicory salads (Cichorium intybus) by highperformance liquid chromatography with diode array detection and electrospray ionisation tandem mass spectrometry. Food Chemistry, 138(2-3), 1062-1071. http://dx.doi.org/10.1016/j.foodchem.2012.11.060.

Cataldo, D. A., Maroon, M., Schrader, L. E., \& Youngs, V. L. (1975). Rapid colorimetric determination of nitrate in plant tissue by nitration of salicylic acid. Communications in Soil Science E Plant Analysis, 6(1), 71-80. http://dx.doi.org/ 10.1080/00103627509366547.

Chennupati, P., Seguin, P., \& Liu, W. (2011). Effects of high temperature stress at different development stages on soybean isoflavone and tocopherol concentrations. Journal of Agricultural and Food Chemistry, 59(24), 13081-13088. http://dx.doi.org/10.1021/jf2037714.

Csizinszky, A. A. (1999). Yield response of herbs to nitrogen andpotassium in sand in multiple harvests. Journal of Herbs, Spices \& Medicinal Plants, 6(4), 11-22. http:// dx.doi.org/10.1300/J044v06n04.

Dhillon, N., Lin, C., Sun, Z., Hanson, P., Ledesma, D., Habicht, S., \& Yang, R. (2016). Varietal and harvesting stage variation in the content of carotenoids, ascorbic acid and tocopherols in the fruit of bitter gourd (Momordica charantia L.). Plant Genetic Resources. http://doi.org/https://doi.org/10.1017/S147926211500057X.

Gent, M. P. N. (2012). Composition of hydroponic lettuce: Effect of time of day, plant size, and season. Journal of the Science of Food and Agriculture, 92(3), 542-550. http://dx.doi.org/10.1002/jsfa.4604.

Ghasemzadeh, A., Jaafar, H. Z. E., Ashkani, S., Rahmat, A., Juraimi, A. S., Puteh, A., \& Muda Mohamed, M. T. (2016). Variation in secondary metabolite production as well as antioxidant and antibacterial activities of Zingiber zerumbet (L.) at different stages of growth. BMC Complementary and Alternative Medicine, 16(1), 104. http://dx.doi.org/10.1186/s12906-016-1072-6.

Graham, I. A., \& Eastmond, P. J. (2002). Pathways of straight and branched chain fatty acid catabolism in higher plants. Progress in Lipid Research, 41(2), 156-181. http://dx.doi.org/10.1016/S0163-7827(01)00022-4.

Jaiswal, R., Kiprotich, J., \& Kuhnert, N. (2011). Determination of the hydroxycinnamate profile of 12 members of the Asteraceae family.

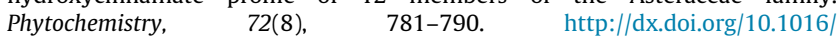
j.phytochem.2011.02.027.

Lee, O., \& Sugiyama, N. (2006). Changes in carbohydrate composition in lettuce flower stalks during development. Journal of Horticultural Science and Biotechnology, 81(5), 928-932.

Lin, K. H., Huang, M. Y., Huang, W. D., Hsu, M. H., Yang, Z. W., \& Yang, C. M. (2013). The effects of red, blue, and white light-emitting diodes on the growth, development, and edible quality of hydroponically grown lettuce (Lactuca sativa L. var. capitata). Scientia Horticulturae, 150, 86-91. http://dx.doi.org/ 10.1016/j.scienta.2012.10.002.

Masclaux-Daubresse, C., Daniel-Vedele, F., Dechorgnat, J., Chardon, F., Gaufichon, L., \& Suzuki, A. (2010). Nitrogen uptake, assimilation and remobilization in plants: Challenges for sustainable and productive agriculture. Annals of Botany, 105(7), 1141-1157. http://dx.doi.org/10.1093/aob/mcq028.

Morales, P., Ferreira, I., Carvalho, a., Sanchez-Mata, M., Camara, M., \& Tardio, J. (2012). Fatty acids profiles of some Spanish wild vegetables. Food Science and Technology International, 18(3), 281-290. http://dx.doi.org/10.1177/ 1082013211427798.

Omezzine, F., Bouaziz, M., Simmonds, M. S. J., \& Haouala, R. (2014). Variation in chemical composition and allelopathic potential of mixoploid Trigonella foenum-graecum L. with developmental stages. Food Chemistry, 148, 188-195. http://dx.doi.org/10.1016/j.foodchem.2013.10.040.

Palaniswamy, U. R., McAvoy, R. J., \& Bible, B. (2004). Oxalic acid concentrations in purslane (Portulaca oleraceae L.) is altered by the stage of harvest and the nitrate to ammonium ratios in hydroponics. Scientia Horticulturae, 629(3), 299-305. http://dx.doi.org/10.1016/j.scienta.2004.01.006.
Pereira, C., Barros, L., Carvalho, A. M., \& Ferreira, I. C. F. R. (2011). Nutritional composition and bioactive properties of commonly consumed wild greens: Potential sources for new trends in modern diets. Food Research International, 44 (9), 2634-2640. http://dx.doi.org/10.1016/j.foodres.2011.05.012.

Pereira, C., Barros, L. Carvalho, A. M., \& Ferreira, I. C. F. R. (2013). Use of UFLC-PDA for the analysis of organic acids in thirty-Five species of food and medicinal plants. Food Analytical Methods, 6(5), 1337-1344. http://dx.doi.org/10.1007/ s12161-012-9548-6.

Petropoulos, S. A., Akoumianakis, C. A., \& Passam, H. C. (2005). Effect of sowing date and cultivar on yield and quality of turnip-rooted parsley (Petroselinum crispum ssp. tuberosum). Journal of Food, Agriculture E' Environment, 3(2), 205-207. Retrieved from http://www.world-food.net.

Petropoulos, S. A., Chatzieustratiou, E., Constantopoulou, E., \& Kapotis, G. (2016) Yield and quality of lettuce and rocket grown in floating culture system. Notulae Botanicae Horti Agrobotanici Cluj-Napoca, 44(2), 603-612 http://doi.org/10. $15835 /$ nbha44210611.

Petropoulos, S. A., Fernandes, Â., Barros, L., Ferreira, I. C. F. R., \& Ntatsi, G. (2015). Morphological, nutritional and chemical description of "Vatikiotiko", an onion local landrace from Greece. Food Chemistry, 182, 156-163. http://dx.doi.org/ 10.1016/j.foodchem.2015.03.002.

Petropoulos, S. A., Levizou, E., Ntatsi, G., Fernandes, Â., Petrotos, K., Akoumianakis K., ... Ferreira, I. C. F. R. (2017). Salinity effect on nutritional value, chemical composition and bioactive compounds content of Cichorium spinosum L. Food Chemistry, 214, 129-136. http://dx.doi.org/10.1016/j.foodchem.2016.07.080.

Petropoulos, S. A., Ntatsi, G., Levizou, E., Barros, L., \& Ferreira, I. C. F. R. (2016). Nutritional profile and chemical composition of Cichorium spinosum ecotypes. LWT - Food Science and Technology, 73, 95-101. http://dx.doi.org/10.1016/j. lwt.2016.05.046.

Petropoulos, S., Fernandes, Â., Karkanis, A., Ntatsi, G., Barros, L., \& Ferreira, I. C. F. R (2017). Successive harvesting affects yield, chemical composition and antioxidant activity of Cichorium spinosum L. Food Chemistry, 237, 83-90. http://dx.doi.org/10.1016/j.foodchem.2017.05.092.

Pokkaew, R., Wang, S. H., Liu, C. D., Huang, F. L., Chang, J. C., Lo, C. Y. \& Chiou, R. Y. Y. (2013). Properties and characterization of antioxidant and antiglycative activities for the multiple harvests of aquatic- and field-cultivated peanut leaves and stems. Journal of Functional Foods, 5(1), 327-336. http://dx.doi.org/ 10.1016/j.jff.2012.11.003.

Poli, F., Sacchetti, G., Tosi, B., Fogagnolo, M., Chillemi, G., Lazzarin, R., \& Bruni, A. (2002). Variation in the content of the main guaianolides and sugars in Cichorium intybus var. "Rosso di Chioggia" selections during cultivation. Food Chemistry, 76(2), 139-147. http://dx.doi.org/10.1016/S0308-8146(01)00254-0.

Rees, S., \& Harborne, J. (1985). The role of sesquiterpene lactones and phenolics in the chemical defence of the chicory plant. Phytochemistry, 24(10), 2225-2231. http://dx.doi.org/10.1016/S0031-9422(00)83015-0.

Simopoulos, A. P. (1999). Essential fatty acids in health and chronic disease 1, 2, 70 , 560-569.

Tardío, J., Pardo-de-santayana, M., \& Morales, R. (2006). Ethnobotanical review of wild edible plants in Spain. Botanical Journal of the Linnean Society, 152, $27-71$.

Watanabe, T., Maejima, E., Urayama, M., Owadano, M., Yamauchi, A., Okada, R., .. Osaki, M. (2016). Distribution of minerals in young and mature leaves of different leaf vegetable crops cultivated in a field. Open Journal of Plant Science, 1 (1), 5-9.

Wojciechowska, R., Dugosz-Grochowska, O., Koton, A., \& Zupnik, M. (2015). Effects of LED supplemental lighting on yield and some quality parameters of lamb's lettuce grown in two winter cycles. Scientia Horticulturae, 187, 80-86. http://dx. doi.org/10.1016/j.scienta.2015.03.006.

Zeghichi, S., Kallithraka, S., \& Simopoulos, A. P. (2003). Nutritional Composition of Molokhia (Corchorus olitorius) and Stamnagathi (Cichorium spinosum). World Review in Nutrition and Dietetics, Vol. 91.

Zhu, D., Wang, Y., Du, Q., Liu, Z., \& Liu, X. (2015). Cichoric Acid Reverses Insulin Resistance and Suppresses Inflammatory Responses in the GlucosamineInduced HepG2 Cells. Journal of Agricultural and Food Chemistry, 63(51), 10903-10913. http://dx.doi.org/10.1021/acs.jafc.5b04533. 